\title{
Correction: Gene expression profiling identifies $F Y N$ as an important molecule in tamoxifen resistance and a predictor of early recurrence in patients treated with endocrine therapy
}

\author{
D. Elias ${ }^{1} \cdot$ H. Vever ${ }^{1} \cdot$ A.-V. Lænkholm ${ }^{2} \cdot$ M. F. Gjerstorff ${ }^{1} \cdot$ C. W. Yde ${ }^{3} \cdot$ A. E. Lykkesfeldt ${ }^{3} \cdot$ H. J. Ditzel ${ }^{1,4}$
}

Published online: 21 September 2018

(c) The Author(s) 2018. This article is published with open access

Correction to: Oncogene https://doi.org/10.1038/onc.2014. 138; published online 2 June 2014.

Since the online publication of the above article, the authors have noted errors in subfigures $1 \mathrm{c}$ and $3 \mathrm{~b}$. Therefore, new images of the original immmunocytochemistry stainings have been obtained for Fig. 1c, and the Western blots for siRNA-mediated FYN knockdown in Fig. 3b were repeated. The amended versions of Figs. $1 \mathrm{c}$ and $3 \mathrm{~b}$ are now shown below. The conclusions of this paper are not affected, and the authors sincerely apologize for these errors.
Open Access This article is licensed under a Creative Commons Attribution 4.0 International License, which permits use, sharing, adaptation, distribution and reproduction in any medium or format, as long as you give appropriate credit to the original author(s) and the source, provide a link to the Creative Commons license, and indicate if changes were made. The images or other third party material in this article are included in the article's Creative Commons license, unless indicated otherwise in a credit line to the material. If material is not included in the article's Creative Commons license and your intended use is not permitted by statutory regulation or exceeds the permitted use, you will need to obtain permission directly from the copyright holder. To view a copy of this license, visit http://creativecommons. org/licenses/by/4.0/.
D. Elias

delias@health.sdu.dk

$\bowtie$ H. J. Ditzel

hditzel@health.sdu.dk

1 Department of Cancer and Inflammation Research, Institute of Molecular Medicine, University of Southern Denmark, Odense C, Denmark

2 Department of Pathology, Slagelse Hospital, Slagelse, Denmark

3 Breast Cancer Group, Cell Death and Metabolism, Danish Cancer Society Research Center, Copenhagen, Denmark

4 Department of Oncology, Odense University Hospital, Odense, Denmark 

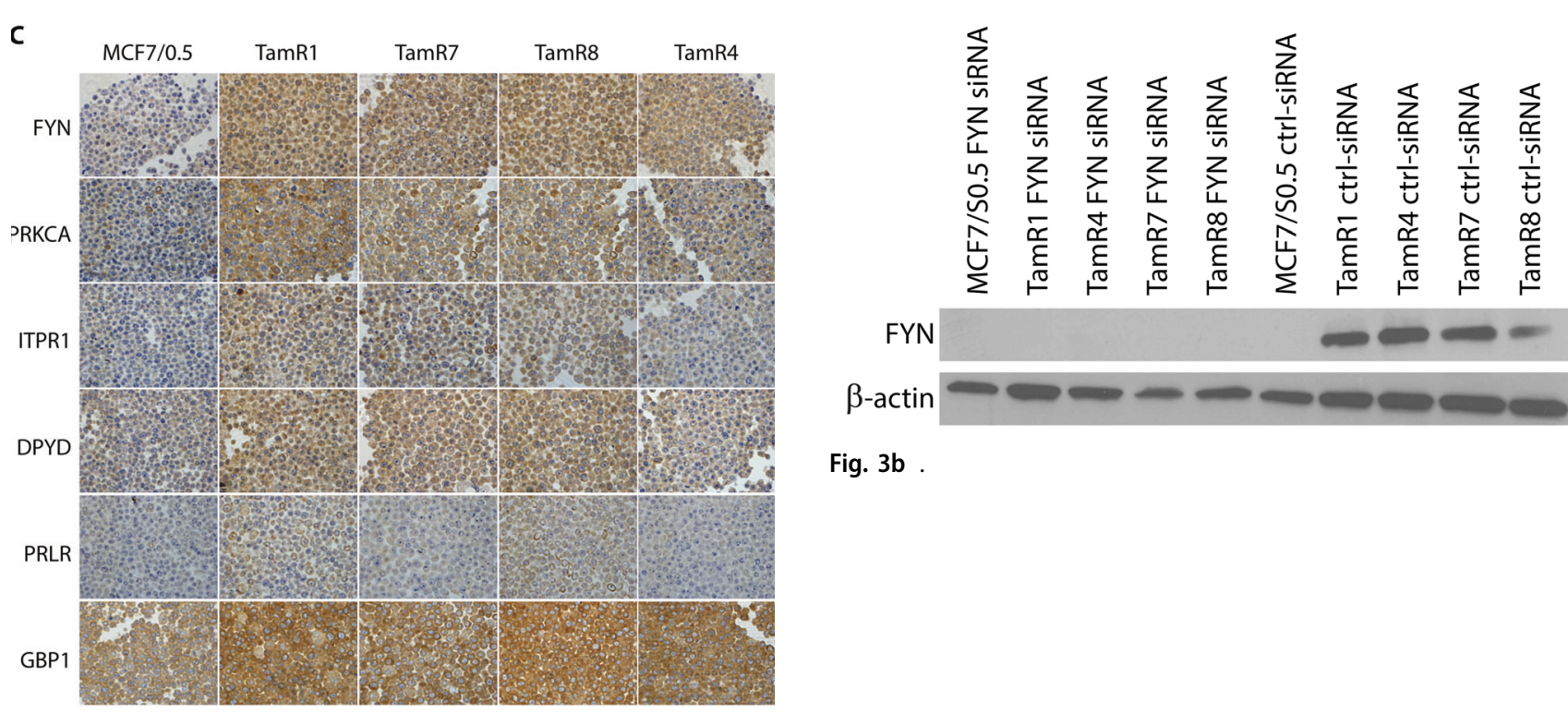

$\beta$-actin

Fig. $3 b$.

Fig. 1c . 